\title{
Synergistic Silencing by Promoter Methylation and Reduced AP-2 $\alpha$ Transactivation of the Proapoptotic HRK Gene Confers Apoptosis Resistance and Enhanced Tumor Growth
}

\author{
Miao $\mathrm{Xu}{ }^{{ }^{\dagger}}$ Xueqin Chen, ${ }^{* \dagger} \mathrm{Ni}$ Chen, ${ }^{*}$ Ling Nie, ${ }^{* \dagger}$ Xinglan $\mathrm{Li}{ }^{* \dagger}$ Qiuyao $\mathrm{Li}^{,}{ }^{* \dagger} \mathrm{Hao} \mathrm{Zeng},{ }^{\ddagger}$ and Qiao Zhou${ }^{* \dagger}$
}

From the Laboratory of Pathology, * State Key Laboratory of Biotherapy and Department of Pathology, the Center for Medical Stem Cell Research ${ }^{\dagger}$ State Key Laboratory of Biotherapy, and the Department of Urology, ${ }^{\ddagger}$ West China Hospital, Sichuan University, Chengdu, China

\author{
Accepted for publication \\ September 18, 2012. \\ Address correspondence to \\ Qiao Zhou, M.D., Ph.D., \\ Department of Pathology, West \\ China Hospital, West China \\ Medical School, Sichuan \\ University, Chengdu, China \\ 610041. E-mail: zhouqiao@ \\ mcwcums.com.
}

\begin{abstract}
The Harakiri $(H R K)$ gene encodes an important proapoptotic mitochondrial protein of the Bcl-2 family. $H R K$ is expressed in normal tissues but is decreased in many cancers such as melanoma, the mechanisms of which have not been fully elucidated. Here, we demonstrate that $H R K$ is silenced by hypermethylation of a major proximal $\mathrm{CpG}$ island in the HRK promoter. Furthermore, we show that HRK is a novel target gene regulated by the transcription factor AP- $2 \alpha$, which interacts with an AP- $2 \alpha$ binding site in the HRK promoter. Hypermethylation of the major proximal $\mathrm{CpG}$ island (which contains the AP-2 $\alpha$ binding site within the most densely methylated -218 - to $-194-$ bp region) inhibited AP-2 $\alpha$ binding and transcriptional activity. Artificial overexpression of AP-2 $\alpha$ in melanoma cells up-regulated HRK transcription, which was further restored by treatment with DNA methyltransferase inhibitor 5-azacytidine. Artificial overexpression of HRK by recombinant adenovirus induced caspase-dependent apoptosis, inhibited melanoma cell growth in vitro, and markedly reduced in vivo melanoma growth in a nude mouse xenograft model. RNA interference by siHRK or siAP- $2 \alpha$ reversed the above effects. We conclude that the synergistic effects of HRK promoter hypermethylation and loss of AP-2 $\alpha$ transactivation lead to $H R K$ gene silencing and confer resistance to apoptosis and enhanced tumor growth. These novel molecular lesions may provide the basis for new therapeutic approaches to treating AP-2 $\alpha-$ and HRKdeficient cancers. (Am J Pathol 2013, 182: 84-95; http://dx.doi.org/10.1016/j.ajpath.2012.09.018)
\end{abstract}

Harakiri (HRK) is a $\mathrm{BH} 3$-only member of the proapoptotic group of the B-cell lymphoma 2 (Bcl-2) family, which promotes apoptosis through the endogenous, mitochondrial pathway by binding to $\mathrm{Bcl}-2 / \mathrm{Bcl}-\mathrm{xL}$ or $\mathrm{p} 32$, a mitochondrial permeability transition pore (MPTP)-related protein, ${ }^{1,2}$ thus releasing cytochrome $c$ and second mitochondria-derived activator of caspases/direct IAP binding protein with low PI (Smac/DIABLO) and activating the caspase cascade.

$H R K$ is expressed in various types of normal tissue. ${ }^{1,3}$ Only a few studies linked loss of heterozygosity or DNA methylation (mainly by methylation-specific PCR) to decreased $H R K$ expression in colorectal and gastric cancer, prostate carcinoma, astrocytoma and glioblastoma, and nonHodgkin's lymphoma of the central nervous system. ${ }^{3-6}$ The precise methylation status of the proximal promoter and its role in regulating $H R K$ transcription by interacting with specific transcription factors have not been elucidated.

The pleiotropic transcription factor activator protein-2 $\alpha$ (AP-2 $\alpha /$ TFAP2a) is a member of the AP-2 family, which binds to CG-rich sequences, up-regulates such genes as $p 21^{W A F 1 / C I P 17}$ and $c-K I T{ }^{8}$ and suppresses vascular endothelial growth factor $(\mathrm{VEGF}),{ }^{9} \mathrm{Bcl}-2,{ }^{10}$ melanoma cell adhesion molecule (MCAM)/MUC18, ${ }^{11}$ protease-activated

\footnotetext{
Supported by grants from the National Natural Science Foundation of China (NSFC 30871383, 30800637, 31071134, 81101529), the Ministry of Education PhD Program Fund (20100181110019), Postdoctoral Fund of China (20100480076, 201104643) and Sichuan University Young Teacher Research Fund (2010SCU11019).
}

M.X. and X.C. contributed equally to this work. 
receptor-1 (PAR-1), ${ }^{12}$ and peroxisome proliferator-activated receptor beta/delta (PPARbeta/delta). ${ }^{13}$ AP- $2 \alpha$ inhibits tumor growth, ${ }^{14}$ induces apoptosis, ${ }^{15}$ suppresses invasion, ${ }^{16}$ and increases sensitivity to chemotherapeutic drugs. ${ }^{17}$ AP$2 \alpha$ is decreased in breast carcinoma, ${ }^{18}$ prostate carcinoma, ${ }^{19}$ colorectal carcinoma, ${ }^{20}$ glioma, ${ }^{21}$ and melanoma. ${ }^{11,22-24}$ Notably, melanoma progression, metastasis, and poor survival have been associated with loss of AP- $2 \alpha$ and its targets p21 and E-cadherin, and overexpression of PAR-1 and MCAM/MUC18. ${ }^{11,22-24}$

We observed a significant decrease of $H R K$ in melanoma cells by gene microarray analysis (unpublished data). Bioinformatics analysis with such tools as CpGPlot (European Bioinformatics Institute, http://www.ebi.ac.uk/Tools/emboss/ cpgplot, last accessed August 11, 2011) indicated that the $H R K$ promoter contained a major proximal $\mathrm{CpG}$ island in the 300-bp region with a putative binding site for the transcription factor AP-2 $\alpha$. We thus hypothesized that $H R K$ promoter hypermethylation and inhibition of AP- $2 \alpha$ transactivation were major mechanisms by which $H R K$ expression was silenced. Here, we use melanoma as a model to show that $H R K$ transcription is significantly decreased due to aberrant DNA methylation of the major proximal $\mathrm{CpG}$ island of the $H R K$ promoter, preventing binding to and transactivation by $\mathrm{AP}-2 \alpha$, with consequent resistance to apoptosis and enhanced tumor growth.

\section{Materials and Methods}

\section{Cells, Tissue Samples, and General Reagents}

Human cancer cell lines HeLa, MCF7, A549, MKN28, Caco2, SW620, SMMC-7721 and HepG-2, RT4, T24, PC3, DU145, LNCaP, T98G, U251, 786-O, GRC-1, and A375 were from ATCC (Manassas, VA). A875, M14, and SK-MEL-1 were obtained from Laboratory of Transplant Engineering and Immunology, Sichuan University (Chengdu, China), the National Cancer Institute (Frederick, MD), and the German Collection of Microorganisms and Cell Cultures (DSMZ, Braunschweig, Germany), respectively. Cells were maintained in RPMI 1640. The human neonatal primary melanocyte HEMn-LP [human epidermal melanocytes (neonatal) lightly pigmented] was purchased from Cascade Biologics (Portland, OR) and maintained in Medium 154 (Invitrogen, Shanghai, China). The human embryonic kidney epithelial cell (HEK293) (ATCC) and umbilical vein endothelial cell (HUVEC) were maintained in Dulbecco's modified Eagle's medium (Gibco, Rockville, MD). Melanoma cells were verified by morphology, immunohistochemistry [for differentiation antigens S-100, melanoma antigen recognized by T-cells 1 (MART1), and human melanoma associated antigen (HMB45)], and transmission electron microscopy (for cytoplasmic premelanosomes and melanosomes). Snap-frozen tissue samples (eight cutaneous and mucosal melanomas, and four dermal nevi) were obtained from West China Hospital with approval of the institutional review committee.
Hoechst 33258 was from Sigma-Aldrich (Saint Louis, MO). Tris base, Tween 20, dithiothreitol, and EDTA were from Amresco (Solon, OH). PMSF, leupeptin, pepstatin, and aprotinin were from Roche Diagnostics (Mannheim, Germany).

\section{RT-PCR and Real-Time qPCR}

Total RNA was extracted with the TRIzol reagent (Invitrogen/Life Technologies, Carlsbad, CA). Revertra Ace reverse transcriptase was from TOYOBO (Osaka, Japan). PCR primers were designed according to cDNA sequences (GenBank) and synthesized by Invitrogen. The primer sequences and product lengths were as follows. HRK: $5^{\prime}$-GGCAGGCGGAACTTGTAGGAAC-3'， 5'-TCCAGGCGCTGTCTTTACTCTCC-3', product length 197 bp; AP-2 $\alpha$ : 5'-ACTCCTTACCTCACGCCATC-3'， 5'-ATAGGGATGGCGGAGACG-3', 136 bp; $\beta$-actin (as internal control): 5'-CTGGCACCACACCTTCTACAATG-3'， 5'-CCTCGTAGATGGGCACAGTGTG-3', 248 bp. PCR products were resolved by agarose gel electrophoresis, stained with the fluorescent dye GoldView (Beijing SBS Genetech, Beijing, China).

The SYBR Green Real-time PCR Master Mix (TOYOBO) was used on a LightCycler 2.0 (Roche Diagnostics), and data collected by LightCycler Software version 4.05. Copy number of target genes (relative to $\beta$-actin) was calculated by $2^{-\Delta \Delta \mathrm{C}_{\mathrm{T}}}$, where $\Delta \Delta \mathrm{C}_{\mathrm{T}}=\Delta \mathrm{C}_{\mathrm{T} \text {-melanoma }}-$ $\Delta \mathrm{C}_{\mathrm{T} \text {-melanocyte }}$ and $\Delta \mathrm{C}_{\mathrm{T}}=\mathrm{C}_{\mathrm{T} \text {-target }}-\mathrm{C}_{\mathrm{T} \text {-actin }}$.

\section{Combined Bisulfite Restriction Analysis and Bisulfite Sequencing}

Combined Bisulfite Restriction Analysis (COBRA) was used to examine the DNA methylation status of the CGCG sequences in the major proximal $\mathrm{CpG}$ island of the $H R K$ promoter by sodium bisulfite modification, PCR amplification, and AccII digestion. Briefly, $1 \mu \mathrm{g}$ of genomic DNA was denatured by $\mathrm{NaOH}(0.2 \mathrm{~mol} / \mathrm{L})$, modified with $3 \mathrm{~mol} / \mathrm{L}$ sodium bisulfite and $10 \mathrm{mmol} / \mathrm{L}$ hydroquinone (pH 5.0, Sigma-Aldrich) in $50^{\circ} \mathrm{C}$ for 16 hours, purified with BioSpin kit (BioFlux, Hangzhou, China), terminated with $0.3 \mathrm{~mol} / \mathrm{L} \mathrm{NaOH}$, and retrieved by ethanol precipitation. The PCR primers were: $5^{\prime}$-GAATTTAGGAAAAGGGGAAGGAG-3', 5'-AACCTCCCCTAAACACCAAATTTC- $3^{\prime}$ (product length: $349 \mathrm{bp}$ ). PCR products were digested by AccII (Takara, Dalian, China) for gel analysis or cloned into pMD18-T vector (Takara) for sequencing (Invitrogen). Data were analyzed with $\mathrm{BiQ}$ Analyzer software (v2.0). ${ }^{25}$

\section{Demethylation Treatment with 5-Azacytidine}

The DNA methyltransferase inhibitor 5-azacytidine (5-aza-C; Sigma-Aldrich) was prepared fresh $(5 \mu \mathrm{mol} / \mathrm{L})$. Cells were cultured for 96 hours in fresh medium with 5-aza-C (replaced every 12 hour) and collected for further analysis. 

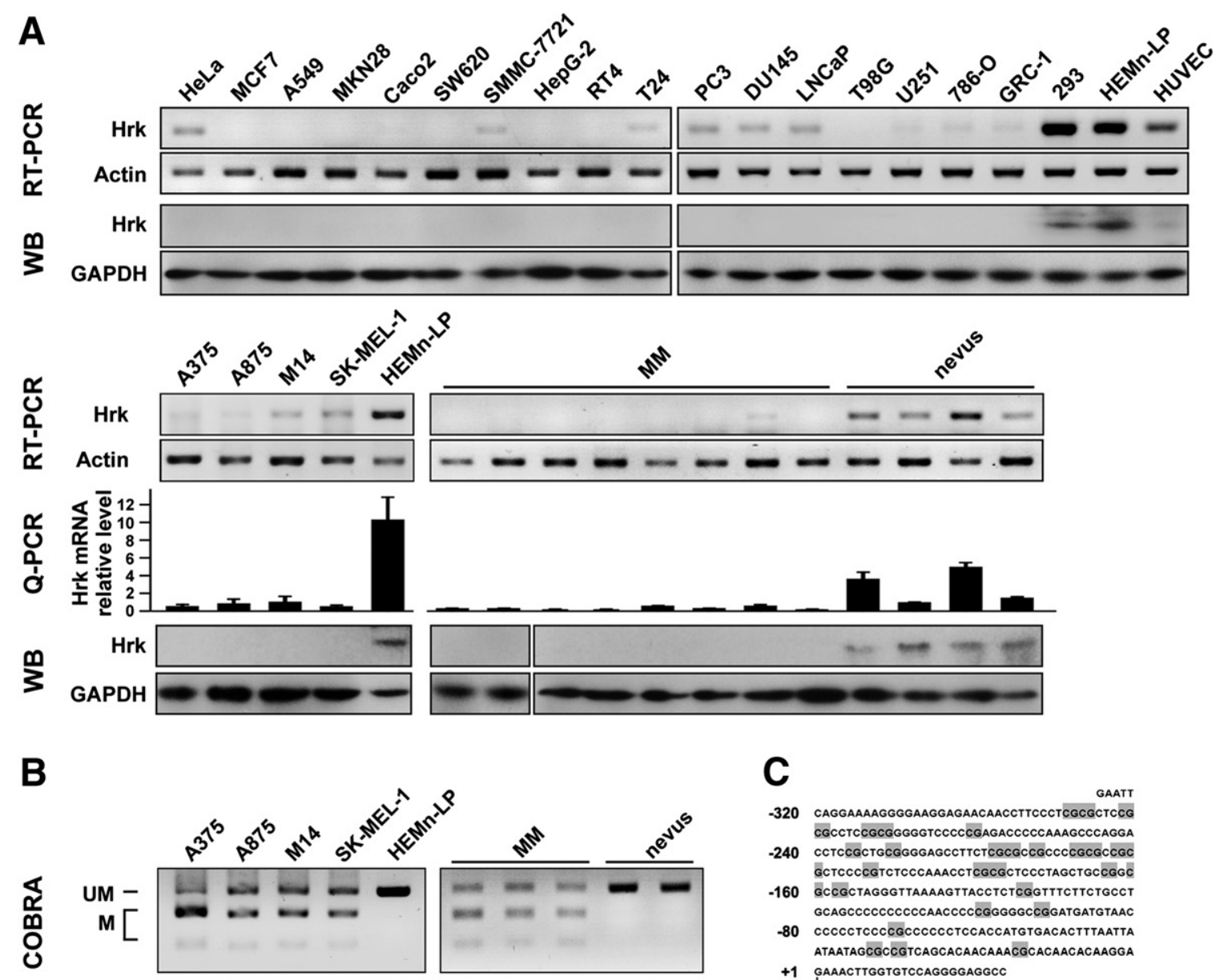

C

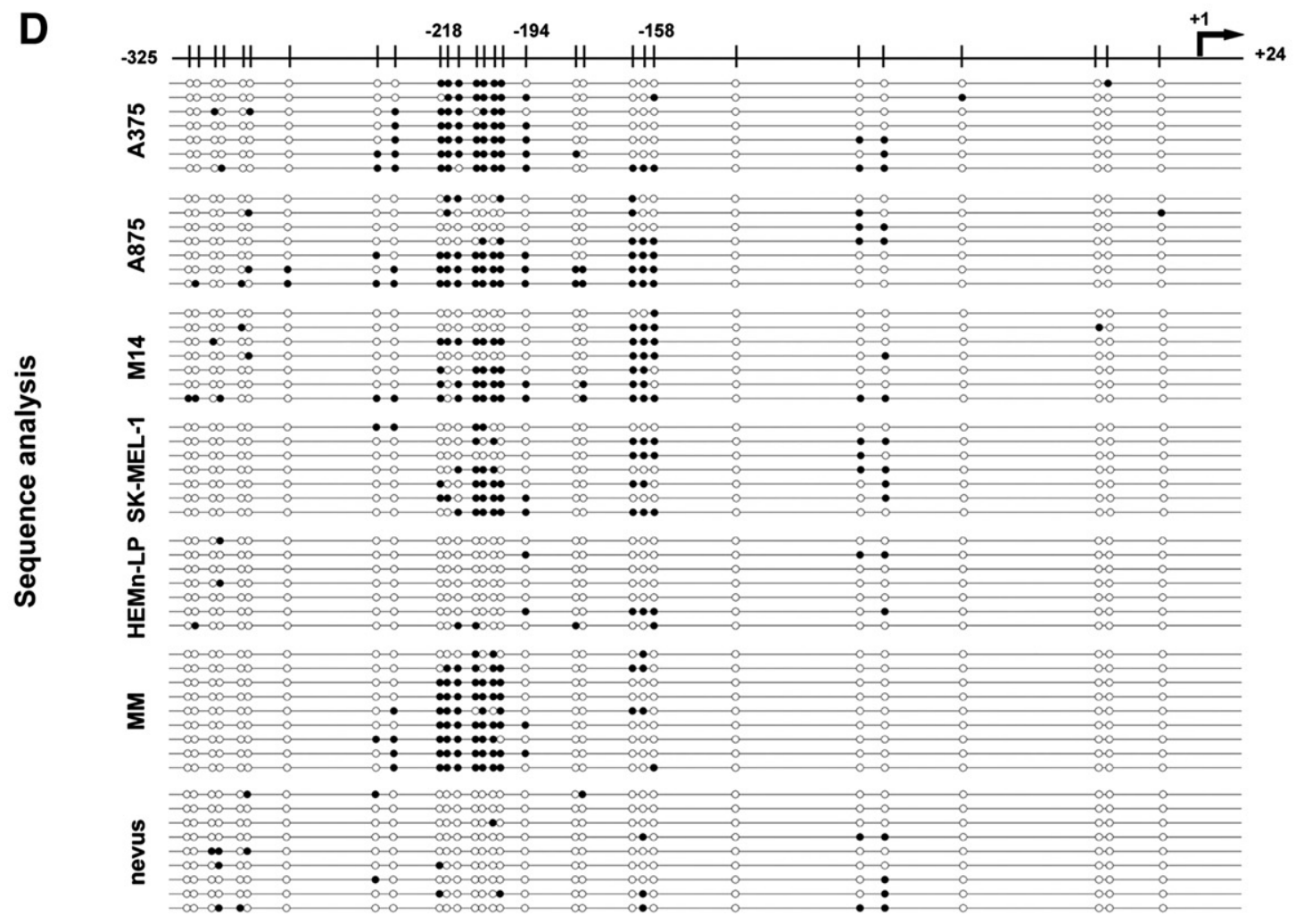




\section{Recombinant Adenoviral Vectors}

The replication-defective recombinant adenovirus for $H R K$ expression was prepared with the AdEasy vector system (Stratagene, La Jolla, CA) as described. ${ }^{26}$ The HRK coding sequence (single exon without introns) was cloned from HEK-293 genomic DNA with primers 5'-AAGCTTCAGCGGTCATGTGCCCGTGC-3' and 5'-GGATCCTACAAGTTCCGCCTGCCGAGC-3' (284 bp). Packaged recombinant $H R K$ adenovirus (Ad-Hrk) was replicated by repeated infection. Recombinant Ad-AP2 $\alpha$ was constructed similarly. The empty pAdTrack-CMV vector was used as control (Ad-Con). Titers and multiplicity of infection (MOI) were determined according to the manufacturer's protocols.

\section{Western Blot Analysis}

Western blot analysis of proteins extracted from cultured cells and tissue samples was performed as described. ${ }^{26-28}$ The primary antibodies used were: Hrk (cocktail containing sc-6971, sc-6972, and sc-26826, goat polyclonal, 1:500) and AP-2 $\alpha$ (sc-184, rabbit polyclonal, 1:1000) from Santa Cruz Biotechnology (Santa Cruz, CA); GAPDH (mouse monoclonal, 1:10,000) from Kangcheng (Shanghai, China). Horseradish peroxidase-conjugated secondary antibodies were from Zymed Laboratories (Zymed/Invitrogen, Carlsbad, CA). Briefly, total proteins were extracted from lysed cells or homogenized tissue samples subjected to sonication for 0.5 minutes in lysis buffer [50 mmol/L Tris $(\mathrm{pH} 8.0), 150 \mathrm{Mm}$ $\mathrm{NaCl}, 1 \%$ Triton X-100, $1 \%$ sodium deoxycholate, $0.1 \%$ SDS, $1 \mathrm{mmol} / \mathrm{L}$ EDTA, $1 \mathrm{mmol} / \mathrm{L}$ PMSF], resolved by SDSPAGE, and electro-blotted onto polyvinylidene difluoride (PVDF) membranes (Amersham Biosciences/GE Healthcare, Little Chalfont, UK). The membranes were blocked with 5\% nonfat milk with $0.1 \%$ Tween 20 , incubated with primary antibodies at $37^{\circ} \mathrm{C}$ for 2 hours, at $4^{\circ} \mathrm{C}$ overnight, and then incubated with secondary antibodies. Signals were detected by exposure to X-ray films after treatment with the ECL chemiluminescence kit (Pierce Biotechnology/Thermo Fisher Scientific, Rockford, IL).

\section{RNA Interference}

Double-stranded small-interfering RNAs (siRNAs) and controls (siCON) were designed, synthesized, and purified (RiboBio, Guangzhou, China). The three specific siRNAs targeting
HRK were designed as follows: 5'-GAGCGATCGTAGAAACACA-3' (siHRK1), 5'-CTATTTACATACAGCTCTA- $3^{\prime}$ (siHRK2), and $5^{\prime}$-GAAGGAAGTGGAGAGTAAA- ${ }^{\prime}$ (siHRK3). The three specific siRNAs targeting AP2 $\alpha$ were: $5^{\prime}$-CACGGACAACAACGCCAAA-3' (siAP2 $\alpha 1$ ), 5'-GGAAGATCTTTAAGAGAAA-3' (siAP2 $\alpha 2$ ), and $5^{\prime}$-GCTCCACCTCGAAGTACAA- $3^{\prime}$ (siAP2 $\alpha 3$ ). Cells were transfected with $0.1 \mathrm{nmol}$ siRNA or siCON and $2 \mu \mathrm{L}$ of Lipofectamine 2000 (Invitrogen) and collected 24 hours post-transfection.

\section{Dual Luciferase Reporter Gene Assay}

The wild-type $H R K$ promoter $(-307$ to +22$)$ containing the AP- $2 \alpha$ binding site (ABS, -213 to -204 ) was cloned into the pGL3-Basic Firefly vector (Promega, Madison, WI) (designated as pGL3-HRKpro-WT) with the primers 5'-AGGAGAACAACCTTCCCTCG-3' and 5'-CCTCCCCTGGACACCAAGT-3' (329 bp). A construct with HRK promoter $(-198$ to +22$)$ lacking the ABS (designated as pGL3-HRKpro- $\triangle \mathrm{ABS}$ ) was constructed similarly with primers 5'-TCCCCGTCTCCCAAACCT- $3^{\prime}$ and 5'-CCTCCCCTGGACACCAAGT-3' (220 bp). The reporter constructs and the pRL-CMV plasmid (Promega) (encoding Renilla luciferase gene, as internal control) were used in dual luciferase reporter gene assays as described. ${ }^{26,28}$

\section{Chromatin Immunoprecipitation}

Chromatin immunoprecipitation assays were performed as described $^{26,28}$ with anti-AP-2 $\alpha$ antibody (rabbit polyclonal; Santa Cruz Biotechnology) or rabbit nonimmune IgG (as negative control). Immunoprecipitated DNA was used for PCR to amplify $H R K$ promoter fragment with primers 5'-AGGAGAACAACCTTCCCTCG-3' and 5'-GCAGGCAGAAGAAACCGAG- $3^{\prime}$.

\section{Electrophoretic Mobility Shift Assay}

The sequence of the wild-type $H R K$ promoter probe for AP-2 $\alpha$ binding was 5'-GGGAGCCTTCTCGCGCCGCCCCGCGCCGCGCTCCCCG-3' ( -229 to -193 , ABS in italic bold face), and the sequence of the mutant probe was 5'-GGGAGCCTTCTCGCGCATTGGTCATACGCGCTCCCCG-3' (mutated ABS in italic bold face). Biotinylated wild-type probe was prepared (Invitrogen), and unlabeled wild-type and mutant probes were used for competition

Figure 1 HRK gene down-regulation and aberrant DNA methylation of the proximal HRK promoter in melanoma. A: Hrk mRNA and protein were significantly decreased in human cancer cells HeLa, MCF7, A549, MKN28, Caco2, SW620, SMMC-7721, HepG-2, RT4, T24, PC3, DU145, LNCaP, T98G, U251, 786-0, GRC-1, A375, A875, M14, SK-MEL-1, and melanoma tissues (MM), compared to HEK293, normal melanocyte HEMn-LP, HUVEC, and benign dermal nevi tissues as assayed by RT-PCR and qPCR (with $\beta$-actin as internal control) and Western blot analysis (mean \pm SD of three independent experiments, $P<0.05$ ). B, C, and $\mathbf{D}$ : Methylation status of the major proximal CpG island of the HRK promoter spanning -325 to $+24 \mathrm{bp}$ (the 349-bp sequence of which was shown in $\mathbf{C}$, with $\mathrm{CpG}$ doublets shaded) as examined by combined bisulfite restriction analysis (COBRA) (with AccII restriction analysis of the $5^{\prime}$-CGCG- $3^{\prime}$ sites) (B) and bisulfite sequencing of the 349-bp PCR products from melanoma cells (A375, A875, M14, and SK-MEL-1) (D), normal melanocyte HEMn-LP, pooled melanoma tissue $(\mathrm{MM}, n=3)$, and benign melanocytic nevus $(n=2)$ samples. M, methylated; UM, unmethylated. Vertical bars: CpG doublets. Black and white dots: methylated and unmethylated $\mathrm{CPG}$ doublets, respectively. The bisulfite sequencing data of seven PCR clones for each cell line, and nine PCR clones for MM and dermal nevus tissue samples were shown by analysis with the BiQ Analyzer software (v2.0). 
A
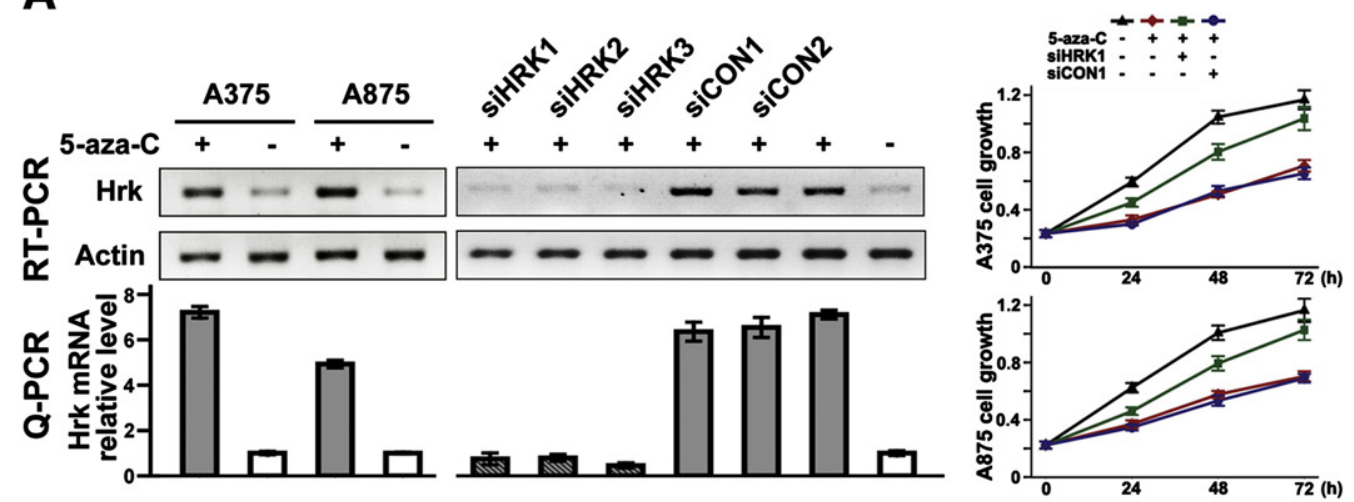

B
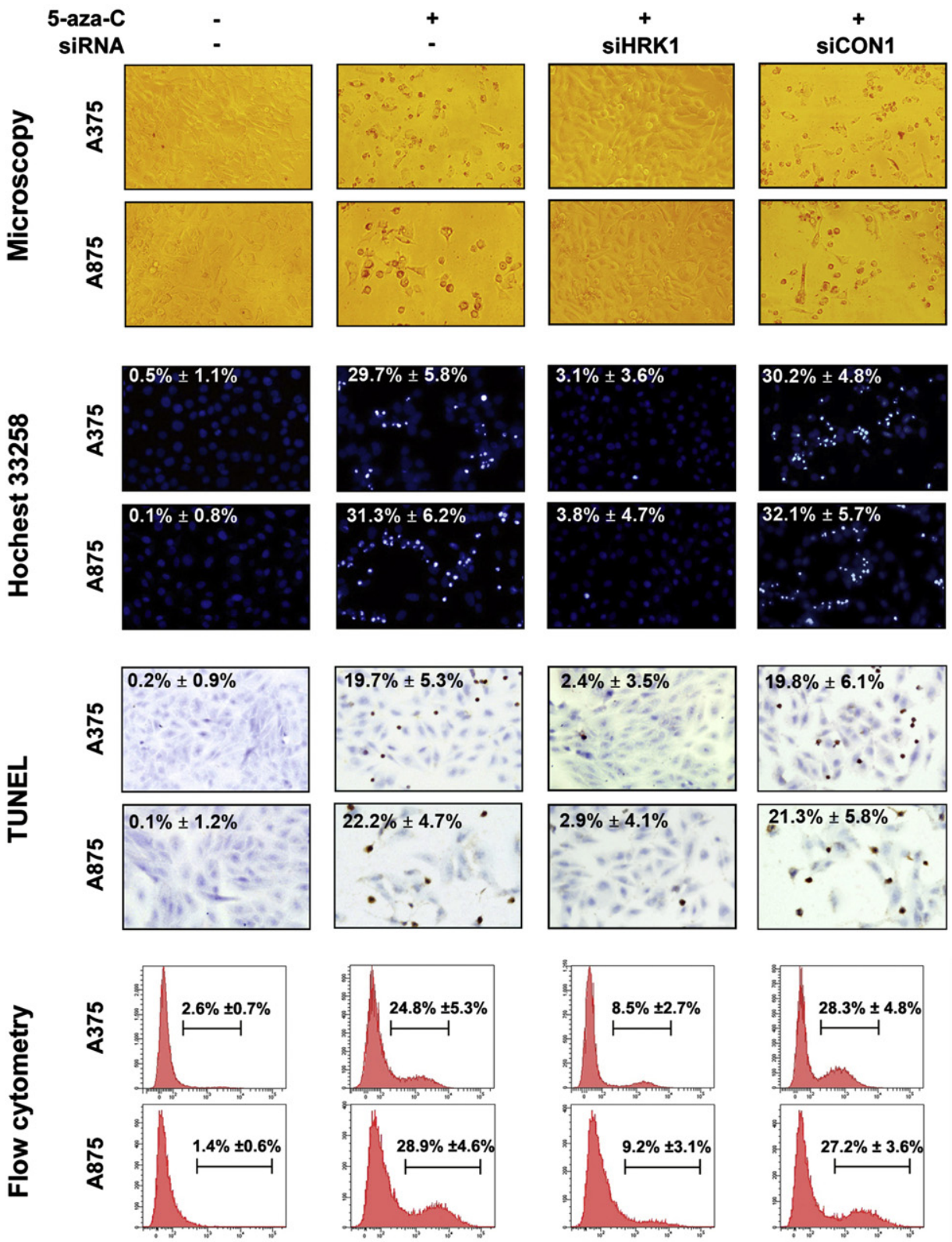

Annexin V-FITC
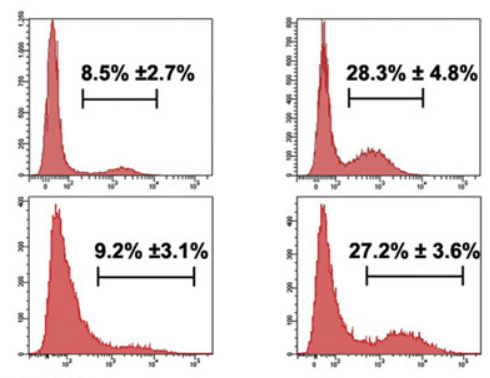
experiments. Double-stranded DNA probes were prepared by mixing equimolar sense and complementary strands. Nuclear extracts from A375 cells with Ad-AP2-mediated overexpression of AP-2 $\alpha$ (MOI 50, infected for 48 hours) were used in electrophoretic mobility shift assays as described. ${ }^{28}$

\section{Cell Viability Assay}

Cells were cultured in 96-well plates and examined by tetrazolium-based MTT (1 mg/mL, Sigma-Aldrich) cell proliferation assay as described. ${ }^{26,28}$

\section{UV Irradiation}

Cells were cultured in 96-well plates and briefly exposed to UV irradiation in a UV cross-linker (UVC-500; Hoefer, San Francisco, CA) at $20 \mathrm{~mJ} / \mathrm{cm}^{2}$ for 30 seconds. Cells were then cultured for subsequent assays.

\section{Flow Cytometry}

Cells were incubated with Annexin V-APC or Annexin V-FITC and propidium iodide in Annexin V binding buffer (BD Pharmingen, BD Biosciences, San Jose, CA) in the dark at room temperature, and analyzed on a BD FACSAria flow cytometer (BD Pharmingen). Nontreated and unstained cells were used as controls. Annexin V-positive/propidium iodide-negative cells were gated as the apoptotic cell population.

\section{Terminal Deoxynucleotidyltransferase-Mediated dUTP Nick End Labeling}

TUNEL was performed by using in situ cell death detection kit (Roche, Mannheim, Germany) as described. ${ }^{26,28}$ The apoptotic index was represented as the number of $\mathrm{TUNEL}^{+}$ cells/total number of cells (\%).

\section{Immunocytochemistry}

The rabbit polyclonal anti-human cleaved (activated) caspase-3 antibody (1:200 dilution; Cell Signaling Technology, Danvers, MA) was used for immunocytochemistry as described. ${ }^{26,28}$

\section{Caspase Inhibition}

Cells were treated with freshly prepared caspase inhibitor $\mathrm{z}-\mathrm{VAD}$-fmk $(50 \mu \mathrm{mol} / \mathrm{L}$ as working concentration; Merck, Nottingham, UK), and cultured for subsequent assays.

\section{Nude Mouse Xenograft Model}

Athymic BALB/c nude mice (6 weeks old, 15 to $20 \mathrm{~g}$ in weight, $n=27$ ) were randomly divided into three groups and maintained under SPF Grade condition (Animal Experiment Center, Sichuan University, Chengdu, China). Xenograft tumor model was established by subcutaneous injection of $3 \times 10^{6}$ A375 cells in the armpit. Ad-Hrk, Adcon $\left(100 \mu \mathrm{L}\right.$ of Ad, $1 \times 10^{9}$ plaque-forming units $\left./ 100 \mu \mathrm{L}\right)$ or PBS $(100 \mu \mathrm{L})$ were administered to the three groups of mice, respectively, by intratumoral injection every 5 days, starting at day 5 post-transplantation (when average tumor diameter reached $0.5 \mathrm{~cm}$ ). The length and width of the xenograft was measured every 5 days. The tumor volume was calculated as $0.5 \times$ length $\times$ width $^{2}$. The mice were sacrificed on day 30 , and the xenografts were excised, weighed, and processed for histopathological examination, immunohistochemistry, and TUNEL analysis.

\section{Results}

\section{HRK Expression Is Significantly Decreased in Human Cancer Cells}

RT-PCR and Western analysis showed significantly decreased expression level of $H R K$ in human cancer cells derived from uterine cervix adenocarcinoma (HeLa), breast carcinoma (MCF7), pulmonary carcinoma (A549), gastric carcinoma (MKN28), colorectal adenocarcinoma (Caco2, SW620), hepatocellular carcinoma (SMMC-7721, HepG-2), urinary bladder urothelial cell carcinoma (RT4, T24), prostate cancer (PC3, DU145, LNCaP), glioblastoma (T98G, U251), renal cell carcinoma (786-O, GRC-1), and melanoma (A375, A875, M14, SK-MEL-1), as compared to normal human embryonic kidney epithelial cell HEK-293, melanocyte HEMn-LP, and HUVEC (Figure 1A, top panel).

HRK expression in melanoma tissues was also significantly lower than in normal melanocyte HEMn-LP and benign melanocytic lesions (nevi) (Figure 1A, middle and bottom panels).

\footnotetext{
Figure 2 Demethylation treatment results in up-regulation of $H R K$ and apoptosis in melanoma cells. A: Significantly increased $H R K$ expression (relative to $\beta$-actin, mean \pm SD of three independent experiments, $P<0.01$, left panels) and decreased cell growth (right panels) in A375 and A875 melanoma cells with 5 -aza-C treatment. siHRK (but not siCON) significantly decreased HRK expression induced by 5 -aza-C treatment and promoted cell growth (MTT assay, mean \pm SD of three independent experiments, $P<0.05$ ). Melanoma cells were first treated with 5 -aza-C for 4 consecutive days (to achieve induction of significant up-regulation of $H R K$ ), and then transfected with siHRK. Cells were then replated and cultured in medium containing 5 -aza-C and post-transfection cell growth was monitored for 72 hours. B: Significant increase of apoptotic cell death with 5-aza-C treatment, shown by conventional microscopy (quantitation by trypan blue staining), Hoechst 33258 staining (apoptotic cells with bright nuclei under fluorescence microscope), TUNEL assays (apoptotic cells showing brownstaining nuclei), and flow cytometry (with Annexin-V-FITC staining for apoptotic cells) in A375 and A875 melanoma cells. Cell death was significantly inhibited by siHRK but not by siCON (numbers shown in each panel are the mean \pm SD of three independent experiments, $P<0.05$ ).
} 
The Proximal HRK Promoter Aberrantly Methylates

COBRA and bisulfite sequencing analysis of the proximal $H R K$ promoter region $(-325$ to +24 , relative to the transcription start site, covering the putative $\mathrm{CpG}$ island with 29 $\mathrm{CpG}$ doublets) identified hypermethylation of the major proximal $\mathrm{CpG}$ island in melanoma cells and tissues, but not in normal melanocytes and benign nevi (Figure 1, B, C, and D). The hypermethylation clustered in the -218 to -158 region, with eight densely methylated ${ }^{5 \mathrm{me}-} \mathrm{CpG}$ doublets in the -218 to -194 region that covered a putative AP- $2 \alpha$ binding site (ABS, 5'-CGCCCCGCGC-3') (Figure 1D).

DNA Methyltransferase Inhibitor Induces HRK Expression, Inhibits Cell Growth, and Promotes Cell Death

Treatment with DNA methyltransferase inhibitor 5-aza-C significantly restored HRK mRNA level (Figure 2A) with concomitant inhibition of melanoma cell growth and promotion of cell death, as shown by the MTT, Hochest33258 staining, TUNEL, and flow cytometry assays (Figure $2 \mathrm{~B})(P<0.05)$.

\section{HRK siRNA Significantly Reduces HRK-Mediated Cell Death}

siRNAs specifically targeting $H R K$ significantly decreased HRK mRNA level despite 5-aza-C treatment, resulting in reduced apoptosis and increased cell survival and cell growth (Figure 2, A and B) $(P<0.05)$. By contrast, siCON had no effect.

\section{Artificial Overexpression of AP-2 $\alpha$ Induces HRK Expression, which Is Enhanced by 5-Aza-C Treatment But Inhibited by siAP2 $\alpha$}

As we postulated AP- $2 \alpha$ to be a transcriptional factor of $H R K$, the expression of AP- $2 \alpha$ was first examined by RT-PCR and qPCR, which showed significantly decreased AP2 $\alpha$ in melanoma cells compared with normal melanocyte HEMnLP at both the mRNA and protein levels (Figure 3A). To demonstrate that $H R K$ was regulated by AP- $2 \alpha$, we first artificially overexpressed AP- $2 \alpha$ in melanoma cells, which resulted in significant induction of $H R K$ expression, concomitant with decrease of $B c l-2$ and $V E G F$, two genes known to be negatively regulated by AP2 $\alpha^{9,10}$ (Figure 3B). Moreover, combination of AP- $2 \alpha$ overexpression with 5-aza$\mathrm{C}$ treatment resulted in further restoration of $H R K$ transcript level in melanoma cells (Figure 3B), whereas knockdown of AP $2 \alpha$ by siRNA (siAP2) significantly down-regulated AP $2 \alpha$ and $H R K$ expression (Figure $3 \mathrm{~B}$ ).

The AP- $2 \alpha$ Binding Site Is Required for HRK Promoter Activity Induced by AP- $2 \alpha$

To further show that the $H R K$ promoter was transcriptionally activated by AP- $2 \alpha$, A375 cells were transfected with the reporter constructs carrying the wild-type promoter (pGL3HRKpro-WT) or constructs in which the ABS was deleted (pGL3-HRKpro- $\Delta$ ABS), respectively. Together with AP-2 $\alpha$ artificial overexpression, the wild-type pGL3-HRKpro-WT demonstrated significantly induced promoter activity shown by relative luciferase activity. By contrast, deletion of the ABS in the pGL3-HRKpro- $\triangle \mathrm{ABS}$ constructs abolished AP- $2 \alpha$-induced promoter activity $(P<0.05)$ (Figure 3C).

\section{Binding with $A B S$ Is Required for Interaction of AP- $2 \alpha$ with the HRK Promoter}

To show binding of AP- $2 \alpha$ to the $H R K$ promoter, chromatin pull down from A375 cells by anti-AP- $2 \alpha$ antibody was used for PCR to amplify a $H R K$ promoter fragment $(-307$ to -119 , containing the ABS). This fragment was readily detected from anti-AP- $2 \alpha$ pull down in A375 cells with Ad-AP2-mediated AP- $2 \alpha$ overexpression, and more abundantly when combined with 5-aza-C treatment. By contrast, in the absence of artificial AP- $2 \alpha$ overexpression, or when nonimmune IgG was used for immunoprecipitation, this fragment could not be identified (Figure 3D).

An electrophoretic mobility shift assay was performed to further confirm physical binding of AP- $2 \alpha$ to $H R K$ promoter. Biotinylated oligonucleotide probe (-229 to -193 , containing the extended putative ABS) caused gel mobility shift when incubated with nuclear proteins extracted from A375 cells with AP- $2 \alpha$ artificial overexpression (Figure 3E). The shift was suppressed in competition experiments with excess of unlabeled wild-type probe, but not with the unlabeled mutant probe (Figure 3E).

Artificial Overexpression of HRK Results in Melanoma Cell Growth Inhibition, UV Irradiation Sensitization, and Caspase-Dependent Apoptosis

Having demonstrated transcriptional activation by AP- $2 \alpha$ of the $H R K$ promoter, and hypermethylation of which silenced $H R K$ expression, we then turned to show the biological effects of artificial $H R K$ overexpression in melanoma cells. Concomitant with Ad-Hrk-mediated HRK overexpression (MOI 40, 96 hours), melanoma cells showed significantly reduced cell growth (Figure 4, A and B), dramatically increased apoptosis (Figure 4C), and sensitization to UV irradiation (Figure 4B). HRK overexpression-induced cell death was caspase dependent, and could be effectively inhibited by the potent caspase inhibitor z-VAD-fmk (Figure 4, D-F).

\section{HRK Inhibits Tumor Growth in Vivo}

The in vivo effects of Ad-Hrk infection was further shown in nude mouse melanoma xenograft tumor model, which demonstrated intratumoral injection of Ad-Hrk resulted in marked inhibition of tumor growth together with significantly high levels of $H R K$ in xenograft tumor tissue (Figure 5A). The weight and size of Ad-Hrk-treated xenograft tumors were 
B
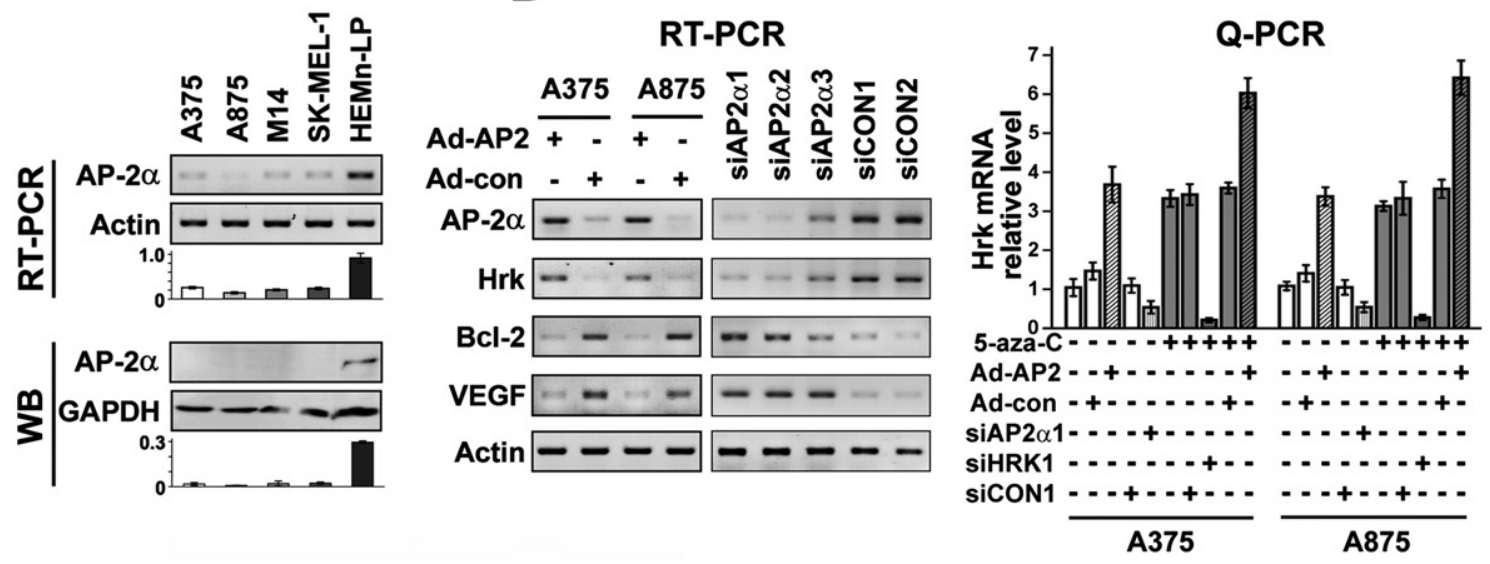

C Luciferase assay

D
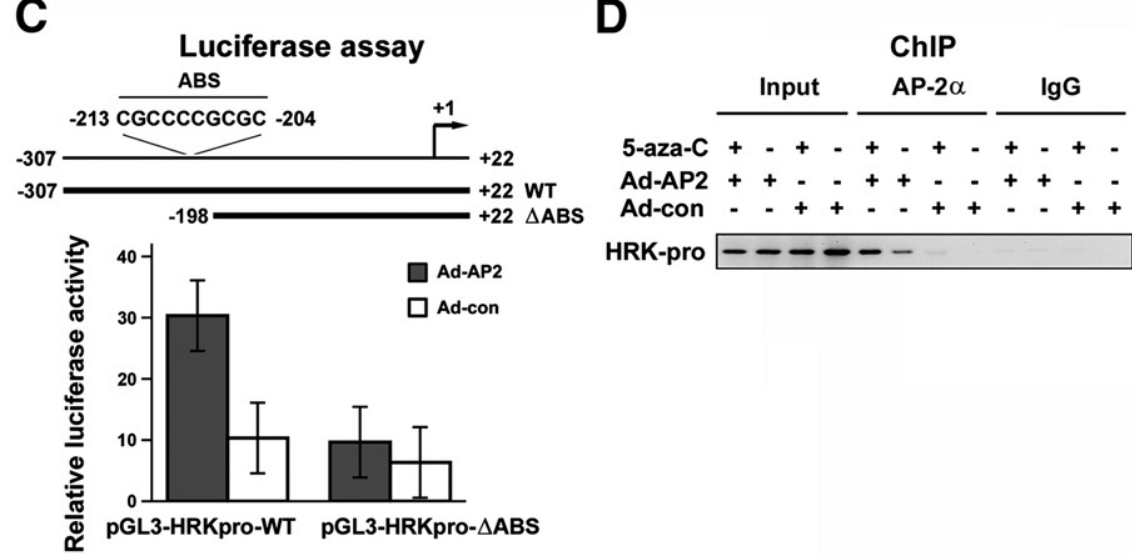

$\mathbf{E}$

EMSA

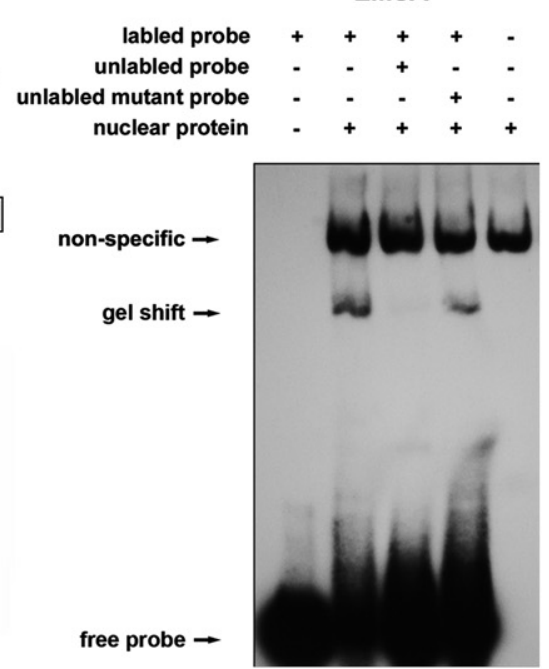

Figure 3 Binding to and transcriptional activation by AP-2 $\alpha$ of HRK promoter. A: Expression of AP-2 $\alpha$ mRNA (RT-PCR) and protein (Western blot, WB) were significantly decreased in melanoma cells A375, A875, M14, and SK-MEL-1, compared with melanocyte HEMn-LP (histograms showing semiquantitative analysis of two independent experiments, $P<0.05)$. B: Ad-AP2 mediated AP-2 $\alpha$ overexpression led to increase of $H R K$ expression, together with decrease of $B C l-2$ and VEGF (two genes known to be negatively regulated by AP- $2 \alpha$ ) in A375 and A875 cells. AP- $2 \alpha$ overexpression combined with 5 -aza-C treatment resulted in even more increase of $H R K$ expression, whereas siAP2 $\alpha$ (but not siCON) significantly decreased AP2 $\alpha$ and, consequently, $H R K$ expression (qPCR, mean \pm SD of three independent experiments, $P<0.05)$. C: Dual luciferase reporter gene assays with constructs carrying wild-type $H R K$ promoter $(-307$ to +22$)$ containing the AP-2 $\alpha$ binding site (ABS) at -213 to -204 (pGL3-HRKpro-WT) or the ABS-deleted HRK promoter ( -198 to $+22 ;$ pGL3-HRKpro- $\triangle$ ABS). With Ad-AP2-mediated AP- $2 \alpha$ overexpression, the relative luciferase gene activity (firefly/Renilla) significantly increased with pGL3-HRKpro-WT, but not with pGL3-HRKpro- $\Delta$ ABS (mean \pm SD of three independent experiments, $P<0.05$ ). D: Chromatin immunoprecipitation showing AP-2 $\alpha$ binding to HRK promoter. $P C R$ using chromatin (Input) pulled down by anti-AP-2 $\alpha$ antibody (AP-2 $\alpha$ ) as template yielded HRK promoter fragment (HRKpro, -307 to -119 containing the ABS) in cells with AP- $2 \alpha$ overexpression, which was enhanced by 5 -aza-C treatment. No PCR products were observed when AP- $2 \alpha$ was not overexpressed or when nonimmune IgG (IgG) was used for pull down. E: Electrophoretic mobility shift assay. Biotinylated oligonucleotide probe ( -229 to -193 ; containing the ABS) caused gel shift when incubated with nuclear extracts from Ad-AP2-infected A375 cells. The shift was suppressed by competition with excess of unlabeled wild-type probe, but not with unlabeled ABS-mutant probe.

only about $10 \%$ to $15 \%$ of the control group. Histopathological examination, immunohistochemistry, and TUNEL analysis of the xenograft tumor tissue showed pronounced cell death and caspase-3 activation with intratumoral injection of Ad-Hrk (Figure 5, B-D).

\section{Discussion}

The present study was the first to identify the hypermethylation of the proximal CpG island (-300) of the HRK promoter (with CG doublets clustered at -218 to -158 ) to be a major cause of down-regulation of $H R K$ gene. Furthermore, we identified $H R K$ as a novel target gene regulated by the tumor suppressor transcription factor AP$2 \alpha$. The hypermethylated region of $H R K$ promoter contained an AP- $2 \alpha$ binding site, methylation of which blocked its binding to AP2 $\alpha$. Reduced AP- $2 \alpha$ expression and hindrance to AP- $2 \alpha$ binding to $H R K$ promoter by hypermethylation apparently provided double insurance to prevent $H R K$ expression. 
A
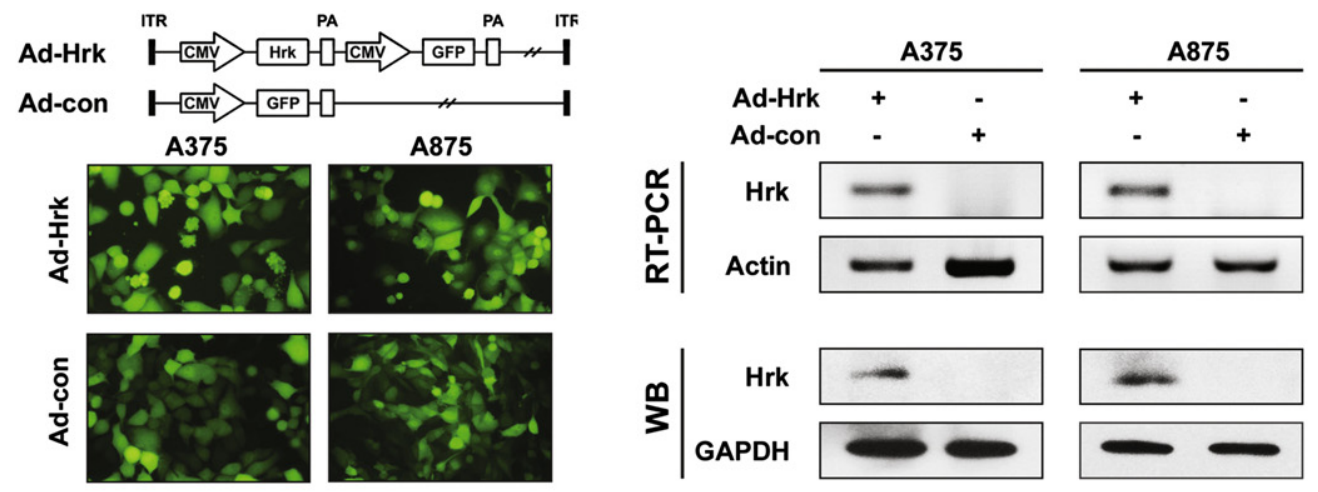

B

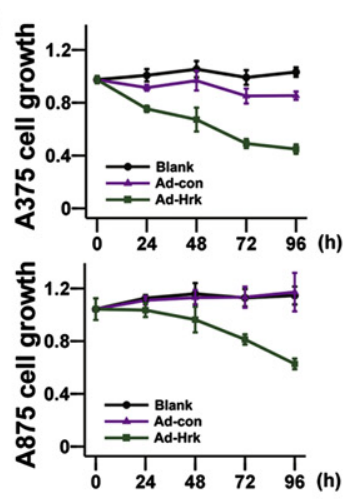

E

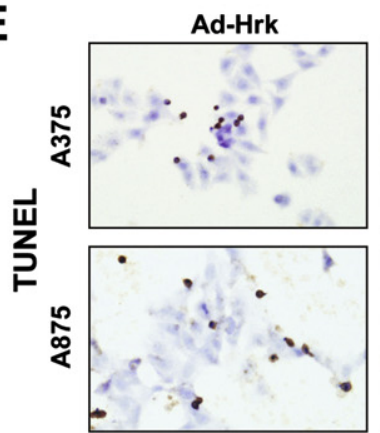

F

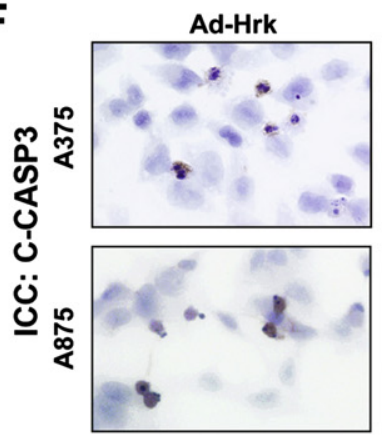

C

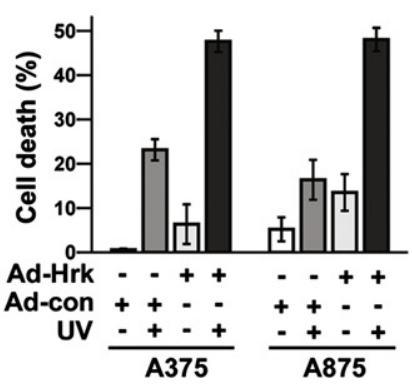

D
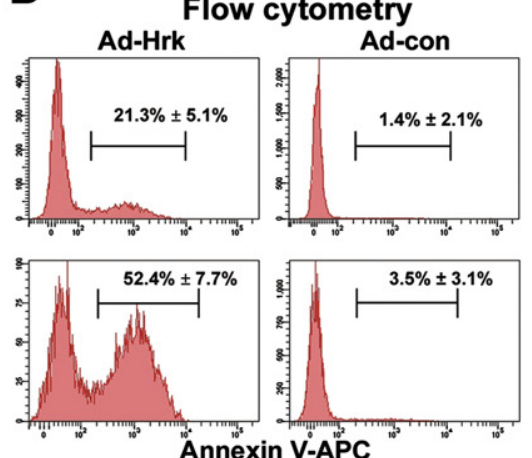

Ad-Hrk + z-VAD-fmk
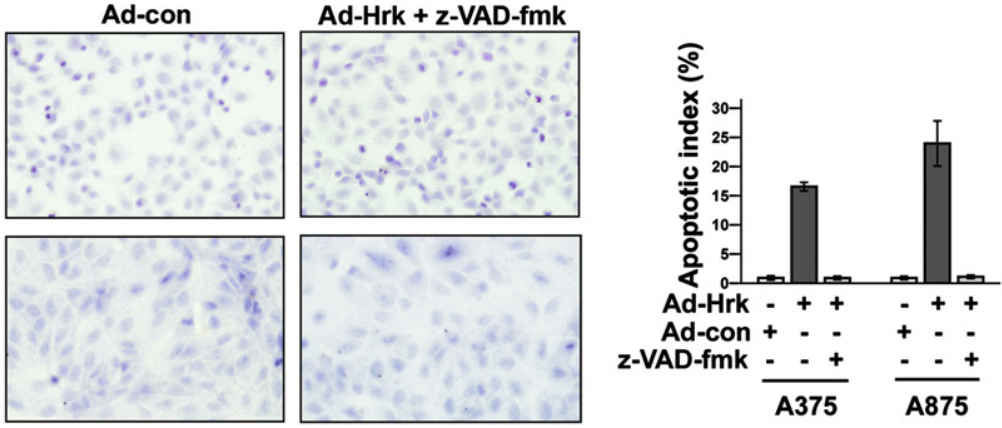

Ad-con

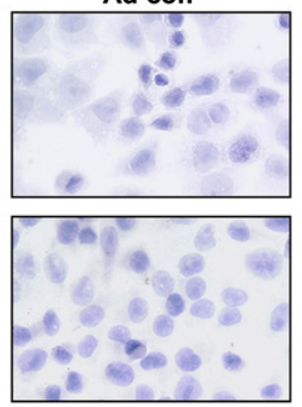

Ad-Hrk + z-VAD-fmk

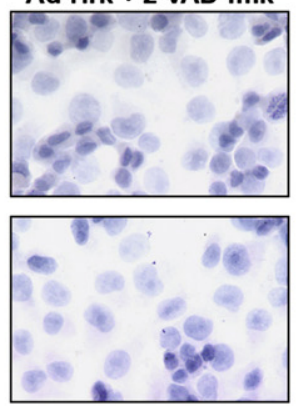

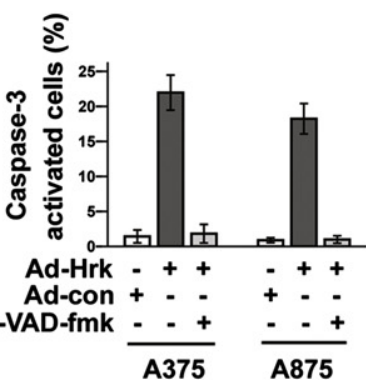

Figure 4 Adenoviral vector-mediated HRK overexpression results in cell growth inhibition, UV irradiation sensitization, and caspase-dependent apoptosis. A: Ad-AP2 infection of melanoma cells was monitored by fluorescence microscopy (for green fluorescence protein) and overexpression of $H R K$ was checked by RT-PCR and WB. Also shown was the recombinant adenoviral vector structure. CMV, cytomegalovirus; GFP, green fluorescence protein; ITR, inverted terminal repeat; PA, poly A. B: Melanoma cells with HRK overexpression $(\mathrm{MOI}=40$ ) showed significant decrease of cell growth (MTT; mean \pm SD of three independent experiments, $P<0.05)$. C: Even low-level artificial HRK expression (MOI $=10)$ was effective to sensitize melanoma cells to apoptosis induced by mild UV irradiation $\left(20 \mathrm{~mJ} / \mathrm{cm}^{2}\right.$ for $\left.30 \mathrm{~s}\right)$ (mean $\pm \mathrm{SD}$ of three independent experiments, $\left.P<0.05\right)$. Flow cytometry (D), TUNEL assays $(\mathbf{E})$, and immunocytochemistry (ICC) (F) demonstrated increased apoptosis with caspase-3 cleavage/activation (C-CASP3, shown by brown-staining granules in apoptotic cells) in melanoma cells with Hrk overexpression (MOI $=40$ ), which was effectively inhibited by the caspase inhibitor z-VAD-fmk (histograms showing the mean \pm SD of three independent experiments, $P<0.05)$. 


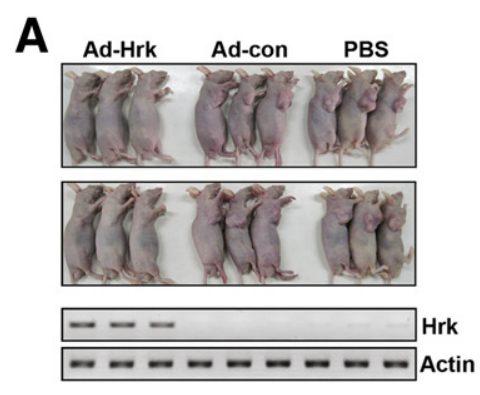

D
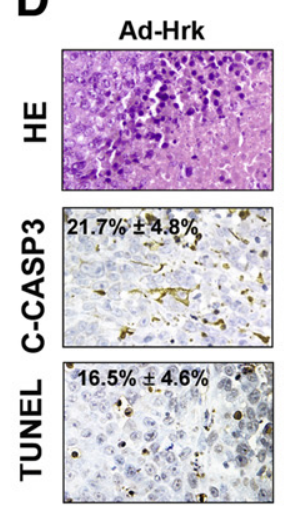

B

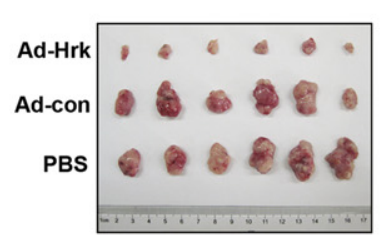

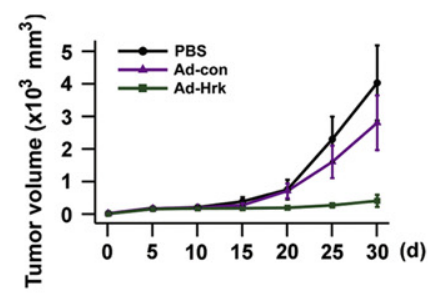

$\mathbf{E}$

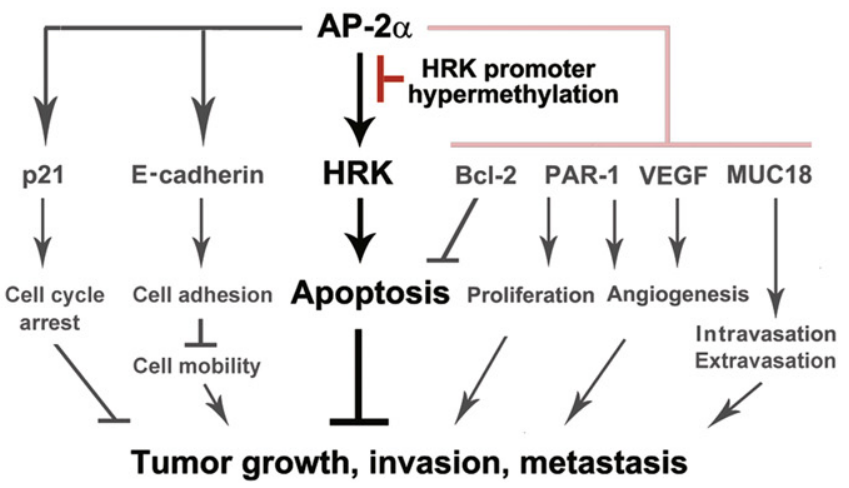

Figure 5 HRK inhibits melanoma growth in vivo. A: Xenograft tumor model in athymic BALB/c nude mice. Intratumoral injection of Ad-Hrk every 5 days (starting at day 5 postimplantation) significantly reduced tumor size (A and $\mathbf{B})$ and weight (C), together with high levels of $H R K$ in tumor tissue extracts (A includes a gel of RT-PCR, with $\beta$-actin as control), compared with Ad-con and PBS treatment $(P<0.05)$. D: Ad-Hrk treatment resulted in significantly increased tumor cell death (HE, hematoxylin and eosin staining), further shown by caspase-3 cleavage/activation assays (C-CASP3: cleaved/activated caspase3 as brown-staining granules in apoptotic cells shown by immunohistochemistry) and apoptosis assays (TUNEL, apoptotic cells showing brown-staining nuclei) in the resected xenograft tumor tissue samples (mean $\pm S D$ of each animal group, $P<0.05$ ). E: Schematic highlights of the findings of the current study in the context of earlier reports of AP-2 $\alpha$ function. In normal cells, AP-2 $\alpha$ binds to its binding site and transcriptionally activates the HRK gene, promoting apoptosis. Decrease of transcription factor AP-2 $\alpha$ and hypermethylation of $H R K$ promoter that prevented binding of AP- $2 \alpha$ in such tumors as melanoma leads to $H R K$ gene silencing and consequent resistance to apoptosis and enhanced tumor growth.

$H R K$ induces cell apoptosis via the mitochondrial pathway $^{1,2}$ and is involved in induced apoptosis of neurons, ${ }^{29-31}$ auditory cells, ${ }^{32}$ pancreatic $\beta$-cells, ${ }^{33}$ and hematopoietic progenitor cells. ${ }^{34}$ Only a few earlier studies examined $H R K$ expression in cancer, which linked loss of heterozygosity or DNA methylation to decreased $H R K$ in colorectal and gastric cancer, prostate carcinoma, astrocytoma and glioblastoma, and non-Hodgkin's lymphoma of central nervous system. ${ }^{3-6}$ Methylation of HRK gene in these studies was mainly examined by methylation specific PCR, ${ }^{4-6}$ although one study showed bisulfite sequencing data of the -18 to +275 bp promoter region in colorectal and gastric carcinoma. ${ }^{3}$ The present study was the first to elucidate the precise methylation status of the proximal promoter (including the major $\mathrm{CpG}$ island identified) and its role in regulating $H R K$ transcription by interacting with a specific transcription factor, AP- $2 \alpha$. It is noteworthy that other BH3-only proapoptotic members, such as BNIP3, Bik, Bim, PUMA, and Noxa, may also be suppressed in various cancers by hypermethylation, contributing to cell death inhibition and neoplasia. ${ }^{35-40}$ Elucidation of the mechanisms of epigenetic modifications of these BH3-only molecules will be an important aspect of future studies.
Our data showed $H R K$ was transcriptionally activated by AP- $2 \alpha$, which required the -213 to -204 AP- $2 \alpha$ binding site $\left(5^{\prime}\right.$-CGCCCCGCGC-3 $\left.{ }^{\prime}\right)$, but was inhibited on hypermethylation of the $H R K$ promoter. This scenario shared features with the regulatory mechanisms of the proenkephalin gene. ${ }^{41}$ Methylation of the proenkephalin gene promoter at a $-72 \mathrm{HpaII}$ (CmCGG) site within the AP-2 binding element obstructed AP- $2 \alpha$ transactivation by preventing its binding to AP-2.

AP- $2 \alpha$ binds to CG-rich sequences, activating or suppressing transcription of target genes. AP- $2 \alpha$ has been shown to up-regulate $\mathrm{p} 21^{\mathrm{WAF} / \mathrm{CIP} 17}$ and $\mathrm{c}-\mathrm{KIT},{ }^{8}$ and to suppress VEGF, ${ }^{9} \mathrm{Bcl}-2,{ }^{10} \mathrm{MCAM} / \mathrm{MUC} 18,{ }^{11} \mathrm{PAR}-1,{ }^{12}$ and PPARbeta/delta. ${ }^{13}$ Biologically, AP- $2 \alpha$ inhibits tumor growth, ${ }^{14}$ induces apoptosis, ${ }^{15}$ suppresses invasion and metastasis, ${ }^{16}$ and increases sensitivity to chemotherapeutic drugs. ${ }^{17}$ Decrease of AP- $2 \alpha$ expression was observed in a variety of cancers, including breast carcinoma, ${ }^{18}$ prostate carcinoma, ${ }^{19}$ colorectal carcinoma, ${ }^{20}$ and glioma. ${ }^{21}$

Deregulation of AP-2 transcription factors has been proposed to be a major abnormality in melanoma. Loss of AP- $2 \alpha$ in melanoma has been considered to be characteristic of melanoma progression (notably from the radial growth to the vertical growth phase), metastasis, and poor survival, in 
association with loss of downstream targets p21 and E-cadherin, overexpression of PAR-1 and MCAM/ MUC18. ${ }^{11,24}$ The mechanisms leading to down-regulation of AP- $2 \alpha$ in melanoma and other neoplasms are less clear. The cAMP-responsive element (CRE)-binding protein/activating transcription factor-1 (CREB/ATF-1) family transcription factors have been implicated in down-regulating the expression of AP- $2 \alpha^{42}$ A recent study also showed overexpression of miR214 resulted in down-regulation of another AP-2 family member, AP- $2 \gamma$ (TFAPC), and enhancement of metastasis in melanoma. ${ }^{43}$

Apart from AP- $2 \alpha$ identified in the present study, there have been very limited data regarding $H R K$ transcriptional regulators. In cerebellar granule neurons, $H R K$ was shown to be transcriptionally regulated by c-Jun and was involved in apoptosis induced by potassium deprivation. ${ }^{31}$ Transcription of $H R K$ could also be activated by transcription factor $\mathrm{E} 2 \mathrm{~F} 1,{ }^{44}$ a cell cycle protein also involved in cell death regulation. Given that E2F1 was overexpressed in melanoma due to gene amplification ${ }^{45}$ and down-regulation of miR-205 (which targeted and inhibited E2F1 expression), ${ }^{46}$ its effects on $H R K$ in melanoma may be more complex. The transcription repressor DREAM (downstream regulatory element antagonist modulator) has been shown to bind to $H R K 3^{\prime}$ untranslated region to inhibit $H R K$ transcription on phosphorylation by the PI3K pathway in hematopoietic progenitor cells ${ }^{47}$ or by the Bcr-Abl fusion kinase in leukemia cells. ${ }^{48}$ A recent report indicated E2F1 overexpression in melanoma cells might promote DREAM homodimerization, reducing its binding activity to the $H R K 3^{\prime}$ untranslated region. ${ }^{49}$ Overall, data on deregulation of $H R K$ transcription or post-transcription control in cancer are still scarce.

In summary, we demonstrated a novel, synergistic mechanism of $H R K$ gene silencing involving both transcriptional and epigenetic mechanisms with major therapeutic implications. Cooperation between decrease of transcription factor AP- $2 \alpha$ and simultaneous hypermethylation of $H R K$ promoter that prevented binding of AP- $2 \alpha$ resulted in loss of $H R K$ expression, and consequent resistance to apoptosis and enhanced tumor growth (Figure 5C). The AP-2 $\alpha-H R K$ pathway may play pivotal roles in tumorigenesis and progression (Figure 5E). As concerted down-regulation of both $H R K$ and AP- $2 \alpha$ have also been observed in a variety of other cancers such as glioma and prostate cancer, particularly during tumor progression, the molecular lesions identified herein may provide a rationale for $H R K$ - and AP- $2 \alpha$-based treatment of these cancers.

\section{References}

1. Inohara $\mathrm{N}$, Ding $\mathrm{L}, \mathrm{Chen} \mathrm{S}, \mathrm{Nunez} \mathrm{G}$ : harakiri, a novel regulator of cell death, encodes a protein that activates apoptosis and interacts selectively with survival-promoting proteins Bcl-2 and Bcl-X(L). EMBO J 1997, 16:1686-1694

2. Sunayama J, Ando Y, Itoh N, Tomiyama A, Sakurada K, Sugiyama A, Kang D, Tashiro F, Gotoh Y, Kuchino Y, Kitanaka C: Physical and functional interaction between BH3-only protein Hrk and mitochondrial pore-forming protein p32. Cell Death Differ 2004, 11:771-781

3. Obata T, Toyota M, Satoh A, Sasaki Y, Ogi K, Akino K, Suzuki H, Murai M, Kikuchi T, Mita H, Itoh F, Issa JP, Tokino T, Imai K: Identification of HRK as a target of epigenetic inactivation in colorectal and gastric cancer. Clin Cancer Res 2003, 9:6410-6418

4. Nakamura M, Ishida E, Shimada K, Nakase H, Sakaki T, Konishi N: Frequent HRK inactivation associated with low apoptotic index in secondary glioblastomas. Acta Neuropathol 2005, 110:402-410

5. Nakamura M, Ishida E, Shimada K, Nakase H, Sakaki T, Konishi N: Defective expression of HRK is associated with promoter methylation in primary central nervous system lymphomas. Oncology 2006, 70: 212-221

6. Higuchi T, Nakamura M, Shimada K, Ishida E, Hirao K, Konishi N: HRK inactivation associated with promoter methylation and $\mathrm{LOH}$ in prostate cancer. Prostate 2008, 68:105-113

7. Zeng YX, Somasundaram K, el-Deiry WS: AP2 inhibits cancer cell growth and activates p21WAF1/CIP1 expression. Nat Genet 1997, 15 : $78-82$

8. Huang S, Jean D, Luca M, Tainsky MA, Bar-Eli M: Loss of AP-2 results in downregulation of c-KIT and enhancement of melanoma tumorigenicity and metastasis. EMBO J 1998, 17:4358-4369

9. Ruiz M, Pettaway C, Song R, Stoeltzing O, Ellis L, Bar-Eli M: Activator protein 2alpha inhibits tumorigenicity and represses vascular endothelial growth factor transcription in prostate cancer cells. Cancer Res 2004, 64:631-638

10. Wajapeyee N, Britto R, Ravishankar HM, Somasundaram K Apoptosis induction by activator protein 2alpha involves transcriptional repression of Bcl-2. J Biol Chem 2006, 281:16207-16219

11. Jean D, Gershenwald JE, Huang S, Luca M, Hudson MJ, Tainsky MA, Bar-Eli M: Loss of AP-2 results in up-regulation of MCAM/MUC18 and an increase in tumor growth and metastasis of human melanoma cells. J Biol Chem 1998, 273:16501-16508

12. Tellez C, McCarty M, Ruiz M, Bar-Eli M: Loss of activator protein2alpha results in overexpression of protease-activated receptor-1 and correlates with the malignant phenotype of human melanoma. J Biol Chem 2003, 278:46632-46642

13. Sun X, Ritzenthaler JD, Zhong X, Zheng Y, Roman J, Han S: Nicotine stimulates PPARbeta/delta expression in human lung carcinoma cells through activation of $\mathrm{PI} 3 \mathrm{~K} / \mathrm{mTOR}$ and suppression of AP-2alpha. Cancer Res 2009, 69:6445-6453

14. Gershenwald JE, Sumner W, Calderone T, Wang Z, Huang S, BarEli M: Dominant-negative transcription factor AP-2 augments SB-2 melanoma tumor growth in vivo. Oncogene 2001, 20:3363-3375

15. Wajapeyee N, Somasundaram K: Cell cycle arrest and apoptosis induction by activator protein 2alpha (AP-2alpha) and the role of p53 and $\mathrm{p} 21 \mathrm{WAF} 1 / \mathrm{CIP} 1$ in AP-2alpha-mediated growth inhibition. J Biol Chem 2003, 278:52093-52101

16. Sumigama S, Ito T, Kajiyama H, Shibata K, Tamakoshi K, Kikkawa F, Williams T, Tainsky MA, Nomura S, Mizutani S: Suppression of invasion and peritoneal carcinomatosis of ovarian cancer cells by overexpression of AP-2alpha. Oncogene 2004, 23:5496-5504

17. Jonckheere N, Fauquette V, Stechly L, Saint-Laurent N, Aubert S, Susini C, Huet G, Porchet N, Van Seuningen I, Pigny P: Tumour growth and resistance to gemcitabine of pancreatic cancer cells are decreased by AP-2alpha overexpression. Br J Cancer 2009, 101: 637-644

18. Pellikainen J, Kataja V, Ropponen K, Kellokoski J, Pietilainen T, Bohm J, Eskelinen M, Kosma VM: Reduced nuclear expression of transcription factor AP-2 associates with aggressive breast cancer. Clin Cancer Res 2002, 8:3487-3495

19. Ruiz M, Troncoso P, Bruns C, Bar-Eli M: Activator protein 2alpha transcription factor expression is associated with luminal differentiation and is lost in prostate cancer. Clin Cancer Res 2001, 7:4086-4095

20. Ropponen KM, Kellokoski JK, Pirinen RT, Moisio KI, Eskelinen MJ, Alhava EM, Kosma VM: Expression of transcription factor AP-2 in colorectal adenomas and adenocarcinomas; comparison of 
immunohistochemistry and in situ hybridisation. J Clin Pathol 2001, 54:533-538

21. Heimberger AB, McGary EC, Suki D, Ruiz M, Wang H, Fuller GN, Bar-Eli M: Loss of the AP-2alpha transcription factor is associated with the grade of human gliomas. Clin Cancer Res 2005, 11:267-272

22. Karjalainen JM, Kellokoski JK, Eskelinen MJ, Alhava EM, Kosma VM: Downregulation of transcription factor AP-2 predicts poor survival in stage I cutaneous malignant melanoma. J Clin Oncol 1998, 16:3584-3591

23. Baldi A, Santini D, Battista T, Dragonetti E, Ferranti G, Petitti T, Groeger AM, Angelini A, Rossiello R, Baldi F, Natali PG, Paggi MG: Expression of AP-2 transcription factor and of its downstream target genes c-kit, E-cadherin and p21 in human cutaneous melanoma. J Cell Biochem 2001, 83:364-372

24. Tellez CS, Davis DW, Prieto VG, Gershenwald JE, Johnson MM, McCarty MF, Bar-Eli M: Quantitative analysis of melanocytic tissue array reveals inverse correlation between activator protein-2alpha and protease-activated receptor-1 expression during melanoma progression. J Invest Dermatol 2007, 127:387-393

25. Bock C, Reither S, Mikeska T, Paulsen M, Walter J, Lengauer T: BiQ Analyzer: visualization and quality control for DNA methylation data from bisulfite sequencing. Bioinformatics 2005, 21:4067-4068

26. Chen X, Gong J, Zeng H, Chen N, Huang R, Huang Y, Nie L, Xu M, Xia J, Zhao F, Meng W, Zhou Q: MicroRNA145 targets BNIP3 and suppresses prostate cancer progression. Cancer Res 2010, 70:2728-2738

27. Yin W, Chen N, Zhang Y, Zeng H, Chen X, He Y, Wang X, Zhou Q: Surviving nuclear labeling index: a superior biomarker in superficial urothelial carcinoma of human urinary bladder. Mod Pathol 2006, 19: 1487-1497

28. Chen N, Chen X, Huang R, Zeng H, Gong J, Meng W, Lu Y, Zhao F, Wang L, Zhou Q: BCL-xL is a target gene regulated by hypoxiainducible factor-1 \{alpha\}. J Biol Chem 2009, 284:10004-10012

29. Imaizumi K, Tsuda M, Imai Y, Wanaka A, Takagi T, Tohyama M: Molecular cloning of a novel polypeptide, DP5, induced during programmed neuronal death. J Biol Chem 1997, 272:18842-18848

30. Young JE, Garden GA, Martinez RA, Tanaka F, Sandoval CM, Smith AC, Sopher BL, Lin A, Fischbeck KH, Ellerby LM, Morrison RS, Taylor JP, La Spada AR: Polyglutamine-expanded androgen receptor truncation fragments activate a Bax-dependent apoptotic cascade mediated by DP5/Hrk. J Neurosci 2009, 29:1987-1997

31. Ma C, Ying C, Yuan Z, Song B, Li D, Liu Y, Lai B, Li W, Chen R, Ching YP, Li M: dp5/HRK is a c-Jun target gene and required for apoptosis induced by potassium deprivation in cerebellar granule neurons. J Biol Chem 2007, 282:30901-30909

32. Kalinec GM, Fernandez-Zapico ME, Urrutia R, Esteban-Cruciani N, Chen S, Kalinec F: Pivotal role of Harakiri in the induction and prevention of gentamicin-induced hearing loss. Proc Natl Acad Sci U S A $2005,102: 16019-16024$

33. Gurzov EN, Ortis F, Cunha DA, Gosset G, Li M, Cardozo AK, Eizirik DL: Signaling by IL-1beta+IFN-gamma and ER stress converge on DP5/Hrk activation: a novel mechanism for pancreatic beta-cell apoptosis. Cell Death Differ 2009, 16:1539-1550

34. Sanz C, Benito A, Inohara N, Ekhterae D, Nunez G, FernandezLuna JL: Specific and rapid induction of the proapoptotic protein Hrk after growth factor withdrawal in hematopoietic progenitor cells. Blood 2000, 95:2742-2747

35. Bacon AL, Fox S, Turley H, Harris AL: Selective silencing of the hypoxia-inducible factor 1 target gene BNIP3 by histone deacetylation and methylation in colorectal cancer. Oncogene 2007, 26:132-141

36. Brodska B, Otevrelova P, Holoubek A: Decitabine-induced apoptosis is derived by Puma and Noxa induction in chronic myeloid leukemia cell line as well as in PBL and is potentiated by SAHA. Mol Cell Biochem 2011, 350:71-80

37. Garrison SP, Jeffers JR, Yang C, Nilsson JA, Hall MA, Rehg JE, Yue W, Yu J, Zhang L, Onciu M, Sample JT, Cleveland JL, Zambetti GP: Selection against PUMA gene expression in Myc-driven B-cell lymphomagenesis. Mol Cell Biol 2008, 28:5391-5402

38. Kim TY, Zhong S, Fields CR, Kim JH, Robertson KD: Epigenomic profiling reveals novel and frequent targets of aberrant DNA methylation-mediated silencing in malignant glioma. Cancer Res 2006, 66:7490-7501

39. San Jose-Eneriz E, Agirre X, Jimenez-Velasco A, Cordeu L, Martin V, Arqueros V, Garate L, Fresquet V, Cervantes F, Martinez-Climent JA, Heiniger A, Torres A, Prosper F, Roman-Gomez J: Epigenetic downregulation of BIM expression is associated with reduced optimal responses to imatinib treatment in chronic myeloid leukaemia. Eur J Cancer 2009, 45:1877-1889

40. Sturm I, Stephan C, Gillissen B, Siebert R, Janz M, Radetzki S, Jung K, Loening S, Dorken B, Daniel PT: Loss of the tissue-specific proapoptotic $\mathrm{BH} 3$-only protein $\mathrm{Nbk} / \mathrm{Bik}$ is a unifying feature of renal cell carcinoma. Cell Death Differ 2006, 13:619-627

41. Comb M, Goodman HM: CpG methylation inhibits proenkephalin gene expression and binding of the transcription factor AP-2. Nucleic Acids Res 1990, 18:3975-3982

42. Melnikova VO, Dobroff AS, Zigler M, Villares GJ, Braeuer RR, Wang H, Huang L, Bar-Eli M: CREB inhibits AP-2alpha expression to regulate the malignant phenotype of melanoma. PLoS One 2010, 5: e12452

43. Penna E, Orso F, Cimino D, Tenaglia E, Lembo A, Quaglino E, Poliseno L, Haimovic A, Osella-Abate S, De Pitta C, Pinatel E, Stadler MB, Provero P, Bernengo MG, Osman I, Taverna D: microRNA-214 contributes to melanoma tumour progression through suppression of TFAP2C. EMBO J 2011, 30:1990-2007

44. Hershko T, Ginsberg D: Up-regulation of Bcl-2 homology 3 (BH3)only proteins by E2F1 mediates apoptosis. J Biol Chem 2004, 279: 8627-8634

45. Nelson MA, Reynolds SH, Rao UN, Goulet AC, Feng Y, Beas A, Honchak B, Averill J, Lowry DT, Senft JR, Jefferson AM, Johnson RC, Sargent LM: Increased gene copy number of the transcription factor E2F1 in malignant melanoma. Cancer Biol Ther 2006, 5:407-412

46. Dar AA, Majid S, de Semir D, Nosrati M, Bezrookove V, KashaniSabet M: miR-205 suppresses melanoma cell proliferation and induces senescence via regulation of E2F1. J Biol Chem 2011, 286: 16606-16614

47. Sanz C, Mellstrom B, Link WA, Naranjo JR, Fernandez-Luna JL: Interleukin 3-dependent activation of DREAM is involved in transcriptional silencing of the apoptotic Hrk gene in hematopoietic progenitor cells. EMBO J 2001, 20:2286-2292

48. Sanz C, Horita M, Fernandez-Luna JL: Fas signaling and blockade of Bcr-Abl kinase induce apoptotic Hrk protein via DREAM inhibition in human leukemia cells. Haematologica 2002, 87:903-907

49. Hao H, Chen C, Rao XM, Gomez-Gutierrez JG, Zhou HS, McMasters KM: E2F-1- and E2Ftr-mediated apoptosis: the role of DREAM and HRK. J Cell Mol Med 2011, 16:605-615 